ARTICLE

\title{
Seasonal dynamics of zooplankton in a northern Chile bay exposed to upwelling conditions
}

\author{
Dinámicas estacionales del zooplancton en una bahía de la zona norte \\ de Chile expuesta a condiciones de surgencias
}

\section{Loreto Torreblanca ${ }^{1}$, Iván Pérez-Santos ${ }^{1,2,3}$, Bruno San Martín ${ }^{1}$, Eduardo Varas ${ }^{1}$, Rodrigo Zilleruelo ${ }^{1}$, Ramiro Riquelme-Bugueño ${ }^{1,4,5}$ and Álvaro T. Palma ${ }^{1,6,7 *}$}

\author{
'Fisioaqua, Avenida Vitacura 2909, oficina 717, Las Condes, Santiago, Chile. *apalma @ fisioaqua.cl \\ ${ }^{2}$ Centro i mar, Universidad de Los Lagos, camino a Chinquihue km 6, Puerto Montt, Chile \\ ${ }^{3}$ Programa COPAS Sur-Austral, Universidad de Concepción, Campus Concepción, Victor Lamas 1290, Concepción, Chile \\ ${ }^{4}$ Departamento de Zoología, Facultad de Ciencias Naturales y Oceanográficas, Universidad de Concepción, Casilla 160-C, Concepción, Chile \\ ${ }^{5}$ Instituto Milenio de Oceanografía, Universidad de Concepción, Concepción, Chile \\ ${ }^{6}$ Universidad Gabriela Mistral, Ricardo Lyon 1177, Providencia, Santiago, Chile \\ ${ }^{7}$ Programa CAPES, Pontificia Universidad Católica de Chile, Av. Libertador Bernardo O’Higgins 340, Santiago, Chile
}

\begin{abstract}
Resumen.- Debido al creciente uso del borde costero con fines industriales, particularmente aquellas actividades que utilizan cantidades importantes de agua de mar, es fundamental entender la composición de la fauna planctónica junto con reconocer su variabilidad espacial y temporal en función de variables hidrográficas relevantes. Totoralillo Norte $\left(\sim 30^{\circ} \mathrm{S}\right)$ es un bahía localizada dentro de un área comúnmente afectada por eventos de surgencia, así como una zona que se proyecta relevante para el desarrollo industrial. Aquí se realizaron muestreos estacionales (varios días en cada estación) durante 2013 y 2014 donde se pudo reconocer una comunidad zooplanctónica abundante con una buena representación de los principales taxa, conformada por al menos 166 especies. Los copépodos dominaron en términos numéricos el holoplancton $(91,7 \%)$, mientras que el meroplancton estuvo compuesto principalmente por estadios larvales de cirripedios, moluscos, decápodos, briozoos y peces. A pesar de ser una zona de la costa normalmente afectada por eventos de surgencia, la abundancia del zooplancton fue elevada durante todo el año, incluso durante períodos dominados por vientos débiles y condiciones de hundimiento. Estudios como este ayudan a develar patrones ecológicos relevantes así como procesos que los afectan; información vital y que debe ser considerada al momento de evaluar impactos ambientales.
\end{abstract}

Palabras clave: Bahía, surgencia, holoplancton, meroplancton, diversidad del zooplancton

\begin{abstract}
Due to the ever-increasing use of the coastline for industrial purposes, particularly by those activities that take up great amounts of sea water, it is fundamental to understand the composition of the planktonic fauna and its natural spatial and temporal variability in relation to hydrographic variables, in order to understand the potential impact of such undertakings. Totoralillo Norte $\left(\sim 30^{\circ} \mathrm{S}\right)$ is an embayment located within a well-known area of recurring upwelling events, as well as a zone with projection for industrial development. Here we performed seasonal surveys (several days sampling within each season) during 2013 and 2014 recognizing an abundant zooplanktonic community with a good representation of the main taxa comprised by at least 166 species. In terms of numbers, copepods dominated the holoplankton (91.7\%), whereas meroplankton was mainly composed of larval stages of barnacles, mollusks, decapods, bryozoans and fish. In spite this being a coastal zone normally affected by upwelling events, zooplankton abundance was high throughout the year, even during periods dominated by weak winds and downwelling conditions. Studies such as this can help unveil relevant ecological patterns and their related processes; vital information that must be considered during an environmental impact assessments.
\end{abstract}

Key words: Bay, upwelling, holoplankton, meroplankton, zooplankton diversity

\section{INTRODUCTION}

The increasing pressure on coastlines for all sorts of human development imposes the need for a detailed understanding of the ecological patterns of the organisms that inhabit these environments, as well as the processes involved. Many of these organisms either undergo a dispersive larval phase (meroplankton) or live throughout their ontogeny in the water column (holoplankton) near the coast. This diversity in life history strategies poses an additional challenge to the understanding of the characteristics and determinants that affect their distribution and abundance.

The zooplankton community includes larval stages of organisms that become benthic after recruiting, whose population dynamics and community structure is directly determined by a variety of transport mechanisms (Morgan \& Fisher 2010). In coastal areas transport mechanisms can intimately be related 
to: the dynamics of the Ekman layer during upwelling events (e.g., Poulin et al. $2002 \mathrm{a}, \mathrm{b}$ ), the effect of wind over surface layers (e.g., Tapia et al. 2004), the presence of upwelling shadows (e.g., Marín et al. 2003, Roughan et al. 2005), occurrence of internal waves (Pineda 1994, 2000) or vertical migration of organisms (e.g., Marta-Almeida et al. 2006, Palma et al. 2011). Within this wide array of processes, upwelling events are among the principal determinants of advection or larval positioning, being both frequent and intense, and affecting the coastal dynamics in the north, north-central and south-central areas of Chile (Montecino \& Quiroz 2000, Moraga et al. 2001, Poulin et al. 2002a, Rutllant et al. 2004, Montecino et al. 2005, Marín et al. 2007).

In north-central coastal Chile, the Coquimbo area $\left(\sim 30^{\circ} \mathrm{S}\right)$ represents a well-known area of coastal upwelling (Montecino \& Quiroz 2000, Moraga et al. 2001, Montecino et al. 2005), where filaments of sub-superficial waters frequently form due to wind as well as 'jet' type flows that contribute to an increased availability of nutrients in the coastal area (Marín et al. 2003a, 2007). In contrast, during periods of calm [from wind intensity] an increase in residence time of dominant currents occurs (Marín et al. 2007). These dynamics represent the main physical factors that affect the circulation patterns on the Chilean coastal zones, and that are thus of potential impact to the planktonic communities therein.

Several studies in northern Chilean coastal areas discuss overall aspects of regional oceanography (e.g., Escribano et al. 2004, Thiel et al. 2007), others emphasize the relationship between zooplankton and conditions associated to upwelling episodes (i.e., Escribano \& Hidalgo 2000, Escribano et al. 2001, Giraldo et al. 2002). Regardless of these generalized studies, basic and detailed information regarding local circulation patterns, as well as descriptions of planktonic communities in coastal areas (i.e., bays and headlands), are scarce (i.e., Palma et al. 2006). Semi-protected embayment systems can display characteristic circulation patterns that have as defining factors the degree of exposure to general oceanographic conditions (Acuña et al. 1989, Palma et al. 2006, 2009). Fairly recent studies describe the effect that smaller bays and geographic barriers have over local circulation and/or planktonic distribution patterns along the coastline (Mace \& Morgan 2006a, b; Palma et al. 2006, Vander Woude et al. 2006, Henríquez et al. 2007, Palma et al. 2009, Morgan \& Fisher 2010).

Given the above background information and the importance that embayments represent for new investment projects along the coast in general, our primary objective is to provide a seasonal description of the zooplanktonic community present in a semi-protected bay in the north of Chile along with the variability of hydrographic patterns at the same scales. To ensure this, the focus was placed on identifying spatial distribution and abundance patterns of planktonic organisms, as well as their relationships to relevant environmental variables (i.e. water column thermal structure, wind patterns). The underlying hypothesis being that an important part of the observed variance in the zooplanktonic community is related to major hydrographic forcing such as upwelling events. To date there are no comprehensive studies that describe the high diversity of the zooplankton present in smaller embayment systems and the related processes that could affect their spatial and temporal patterns of distribution and abundance. Furthermore, such information may deem relevant when decision regarding the implementation of man-made developmental projects (i.e. desalination plants, thermal power plants) could be guided/ improved in order to minimize their environmental impact.

\section{MATERIALS AND METHODS}

\section{STUdy AREA AND SAMPLING PROCEDURES}

Totoralillo Norte $\left(29^{\circ} 45^{\prime} \mathrm{S}, 71^{\circ} 35^{\prime} \mathrm{W}\right.$; $\left.29^{\circ} 49^{\prime} \mathrm{S}-71^{\circ} 35^{\prime} \mathrm{W}\right)$ is a semi-exposed embayment located in north-central Chile that was sampled every season in 2013: austral summer (15-20 January), fall (8-14 June), winter (14-19 August) and spring (November 30-December 8) as well as winter 2014 (10-13 July). We sampled several days within each season in order to capture as much of the inherent variability of the zooplankton distribution and abundance patterns. The bay was divided in several distinct zones with several sampling points within each one: 6 sampling transects at the northern bay, 5 sampling transects at the southern bay, 2 sampling transects outside the southern end of the bay, as well as 4 transects approximately 2 nautical miles offshore (Fig. 1). Only during fall and winter 2013 all the points were visited while fewer were considered during the reminding seasons (although the within-bay points were always sampled). In addition to the zooplankton samples, temperature, salinity and dissolved oxygen profiles were recorded by means of a Hydrolab DS-5 CTD, allowing for an accurate water column characterization of each point down to the maximum possible depth at each coastal point and reaching down to $50 \mathrm{~m}$ at the outer coastal points.

\section{WIND DATA AND DERIVED VARIABLES}

Wind data were obtained from a coastal meteorological station installed in Totoralillo Norte (29 29'30'S-71 $\left.{ }^{\circ} 19^{\prime} 16^{\prime \prime} \mathrm{W}\right)$. Data were recorded every 5 minutes from January 2013 through November 2014. Original data were averaged on an hourly basis to calculate the wind-derived variables. A cumulative 
Figure 1. Area and location of the sampling stations indicating the bathymetry (m). Depths from 0 to $60 \mathrm{~m} /$ Área y localización de las estaciones de muestreo indicando la batimetría (m). Profundidades de 0 a $60 \mathrm{~m}$

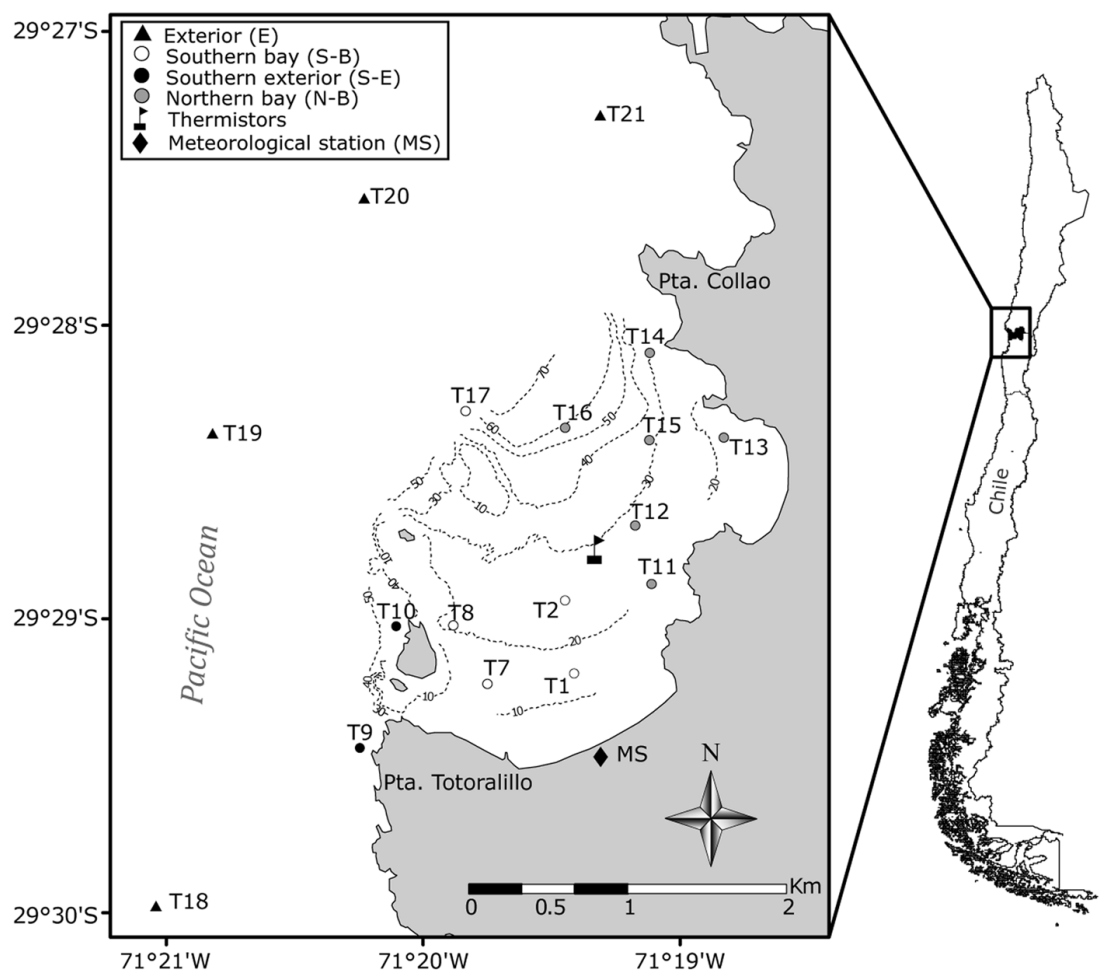

$$
M_{x}=\frac{\tau_{v}}{\rho_{w} f}
$$

where $\tau_{\mathrm{v}}$ is the meridional wind stress vector, $\rho_{\mathrm{w}}$ is the water density $\left(1025 \mathrm{~kg} \mathrm{~m}^{-3}\right)$, and $f$ is the Coriolis parameter.

\section{TEMPERATURE TIME SERIES}

A mooring with a thermistor chain of 5 Hobo Tid bits (Onset Computers) positioned at 4, 11, 16, 19 and $25 \mathrm{~m}$ was installed in a central part of the bay at a depth of $\sim 30 \mathrm{~m}$ (Fig. 1). Temperature was recorded every $15 \mathrm{~min}$ from October 2012 to October 2014, with a resolution of $0.02^{\circ} \mathrm{C}$ and accuracy of $\pm 0.21^{\circ} \mathrm{C}$.

\section{ZOOPLANKTON ABUNDANCE AND DISTRIBUTION}

In each sampling point, zooplankton was collected by means of 3 distinct nets, all of them having the same mesh size (210 $\mu \mathrm{m})$. The surface layer $(0-5 \mathrm{~m})$ was sampled by use of an epineustonic net, towed along a transect of approximately 150 $\mathrm{m}$ in length. The subsurface layer (5-10 $\mathrm{m}$ ) was sampled by use of a bongo net, towed along the same transects. At the end of each transect, a WP-2 net was vertically trawled to capture zooplankton from the bottom layers (>10 m). Each net was equipped with a Hydrobios flowmeter to estimate the volume of water filtered during each tow. 
All samples were maintained at constant temperature until preserved in a solution of formaldehyde (10\%) $24 \mathrm{~h}$ after collection and then transferred to a solution of alcohol for a better handling while identifying and quantifying organisms. Once in the laboratory, plankton samples were identified and quantified following the methodology proposed by Boltovskoy (1981), Olivar \& Fortuño (1991) and Palma \& Kaiser (1993). All zooplankton specimens were counted and identified using Olympus series SZ stereomicroscopes. Each individual was identified and counted with exception of copepods and sometimes decapod crustacean zoea larvae where a Folsom splitter was used, counting the fraction range of 1/2-1/64, depending upon the abundance of individuals in a single sample. Abundances were standardized to $100 \mathrm{~m}^{-3}$. Abundance of all 3 nets used was added in order to obtain the integrated abundance of zooplankton throughout the water column. Total abundance in the water column was then averaged by the number of days surveyed during each seasonal sampling, thus allowing comparisons between seasons.

\section{Statistical analysis}

All datasets were examined for normality using the KolmorogovSmirnov test. Abundance datasets were non-normal distributed and therefore non-parametric statistical analyses were applied. We assessed seasonal and upwelling-related changes in the community structure and the abundances by zooplankton group. For community structure analyses, a classical approach from Field et al. (1982) and Clarke \& Warwick (2001) using PRIMER v6 software (Clarke \& Gorley 2006) was used. Prior to the analyses, samples from the stations common to all the sampling times were selected in order to obtain results consistent and statistically comparable. After that, the data were fourth root transformed to normalize the variance while preserving distances among low values (Field et al. 1982). To test the hypothesis for differences in the community structure among samples from different time periods (seasons) and upwelling regimes, we applied a similarity analysis (ANOSIM test). ANOSIM is a permutation-based nonparametric test (analogue to a one-way analysis of variance), which performs average ranked values of Bray-Curtis measures of dissimilarity in abundances among and within samples. The R statistic is scaled to lie between -1 and +1 , where zero represents the null hypothesis of no differences among a set of samples (Clarke 1993). For abundances of zooplankton groups, statistical differences were assessed with the Kruskal-Wallis test. The descriptive statistical summary presents the median and quartiles (25 and $75 \%$ ) as central tendency and deviation measures, respectively.
Cumulated Ekman transport was computed as described previously where negative values represent offshore transport or coastal upwelling. Average values were used for each sampling season. Cumulated Ekman transport values were categorized as downwelling (DWN, $\approx 14,000 \mathrm{~m}^{2} \mathrm{~s}^{-1}$ ), weak upwelling (LUP, $\approx$ $-20,000 \mathrm{~m}^{2} \mathrm{~s}^{-1}$ ), moderate upwelling (MUP, $\approx-40,000 \mathrm{~m}^{2} \mathrm{~s}^{-1}$ ) and strong upwelling (HUP, $\left.\approx-80,000 \mathrm{~m}^{2} \mathrm{~s}^{-1}\right)$.

The BEST analysis (in Primer software) was applied in order to select the taxa (zooplankton groups) that best correlate with the Cumulated Ekman transport. The BVSTEP stepwise algorithm was used to search the zooplankton groups (best subset) with $>0.95$ and $<0.001 P$-values as removal and addition criterions, respectively.

\section{Results}

\section{Physical setting characterization}

The thermal structure of the water column in Totoralillo Norte presented a clear pattern of higher stratification during the warmer months while during the cooler months there was a higher degree of mixing (Figs. 2a-f). During spring and summer frequent periods of warming and cooling were detected, the highest temperatures were recorded during the summer period $\left(18^{\circ} \mathrm{C}\right)$ and spring only presented moderate warming of the water column $\left(\sim 14^{\circ} \mathrm{C}\right)$ (Figs. 2b, e). A Fourier analysis of the temperature data collected showed that the fluctuations corresponded mostly to daily cycles, particularly evident from the 4 and $16 \mathrm{~m}$ signals (Fig. 2g). The wind stress data exhibited a defined seasonal pattern with periods of high winds (especially zonal) with peaks of intensity during the spring and summer seasons (Figs. 3a, b). Although the upwelling index during these periods was high (Fig. 3c), wind stress averaged during other seasons was not markedly lower. Spectral analysis of the complete wind series recorded at this location revealed prevalence of diurnal and semi-diurnal frequencies (Fig. 3d).

During summer 2013 there was a dominance of winds favorable to the occurrence of upwelling events, and during the sampling period (15-20 January) there were 3 distinguishable upwelling events episodes (Fig. 4a). On the other hand, during fall 2013, winds with weaker characteristics for producing upwelling events alternated with downwelling conditions, albeit during the sampling period (8-14 June) the upwelling index was noticeably at least in 4 opportunities (Fig. 4b). During the winter season of 2013 a scenario similar to the one described for the previous fall was observed, although during August upwelling favorable winds were more dominant, and in at least 3 occasions this occurred during the sampling period (14-19 August, Fig. 4c). During spring, as in summer, there was a predominance of upwelling favorable winds, 


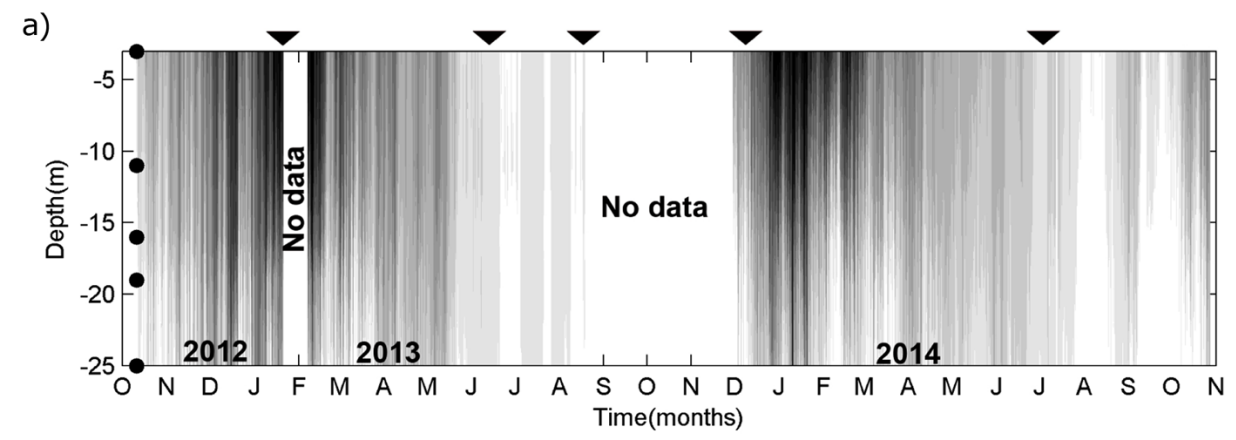

b)

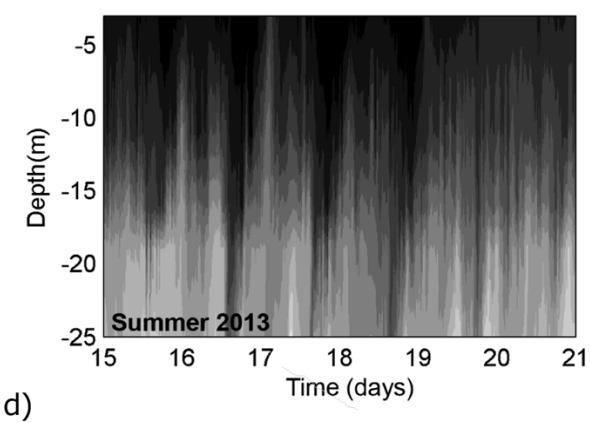

d)

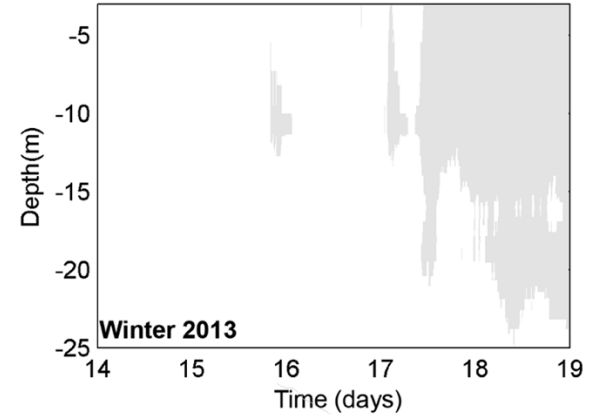

f)

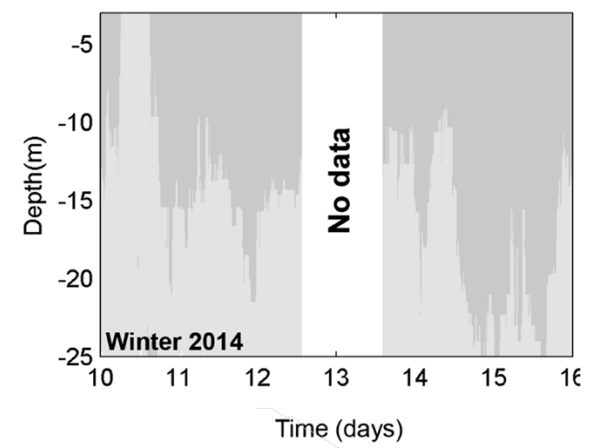

c)

e)
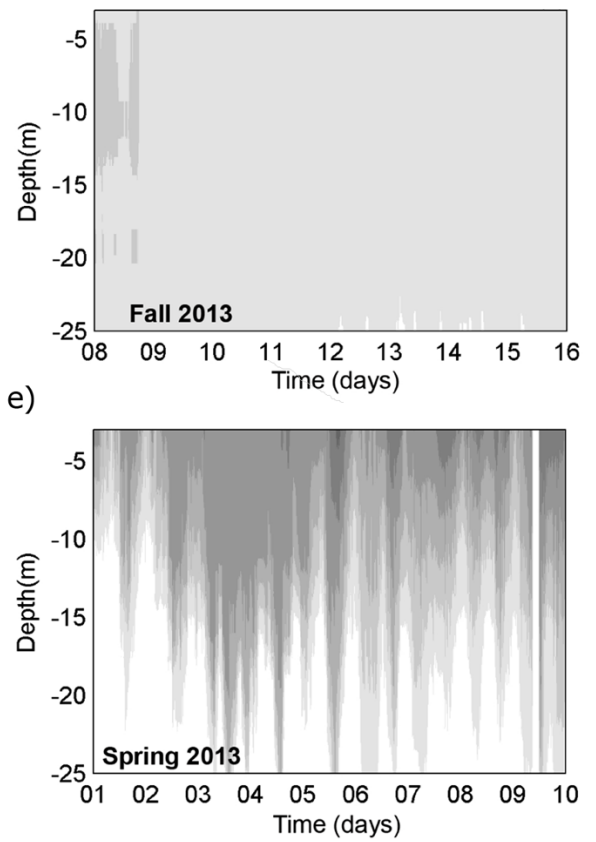

g)

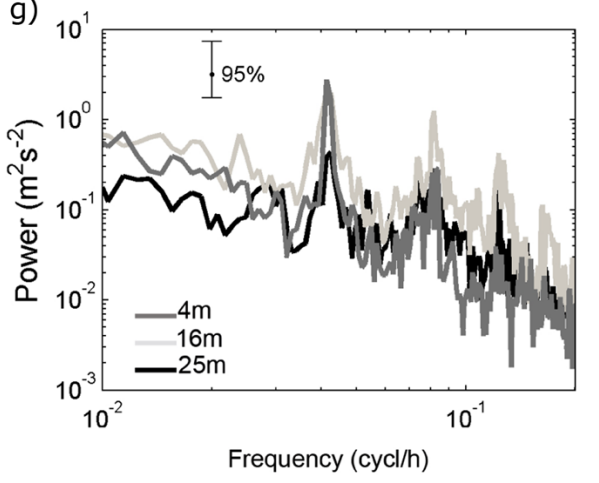

Temperature $\left({ }^{\circ} \mathrm{C}\right)$

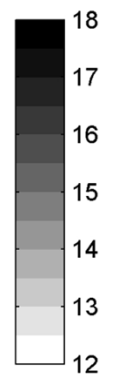

Figure 2. (a) Thermistor chain time series obtained in Totoralillo Norte bay from October 2012 through October 2014. Dots represent the vertical position of the temperature sensors and triangles represent the dates of the different campaigns. (b-f) Daily vertical temperature records obtained during each seasonal campaign. $(\mathbf{g})$ The Fourier spectral analysis to the surface $(4 \mathrm{~m})$, middle $(16 \mathrm{~m})$ and bottom $(25 \mathrm{~m})$ time series / Series de tiempo de la cadena de termistores obtenidos en la bahía Totoralillo Norte desde octubre 2012 a octubre 2014. Los puntos negros representan la posición vertical de los sensores de temperatura y los triángulos representan los datos de las diferentes campañas. (b-f) Registros verticales diarios de la temperatura obtenida durante cada campaña estacional. (g) Series de tiempo del análisis espectral de Fourier en la superficie (4 m), capa media $(16 \mathrm{~m})$ y fondo $(25 \mathrm{~m})$ 

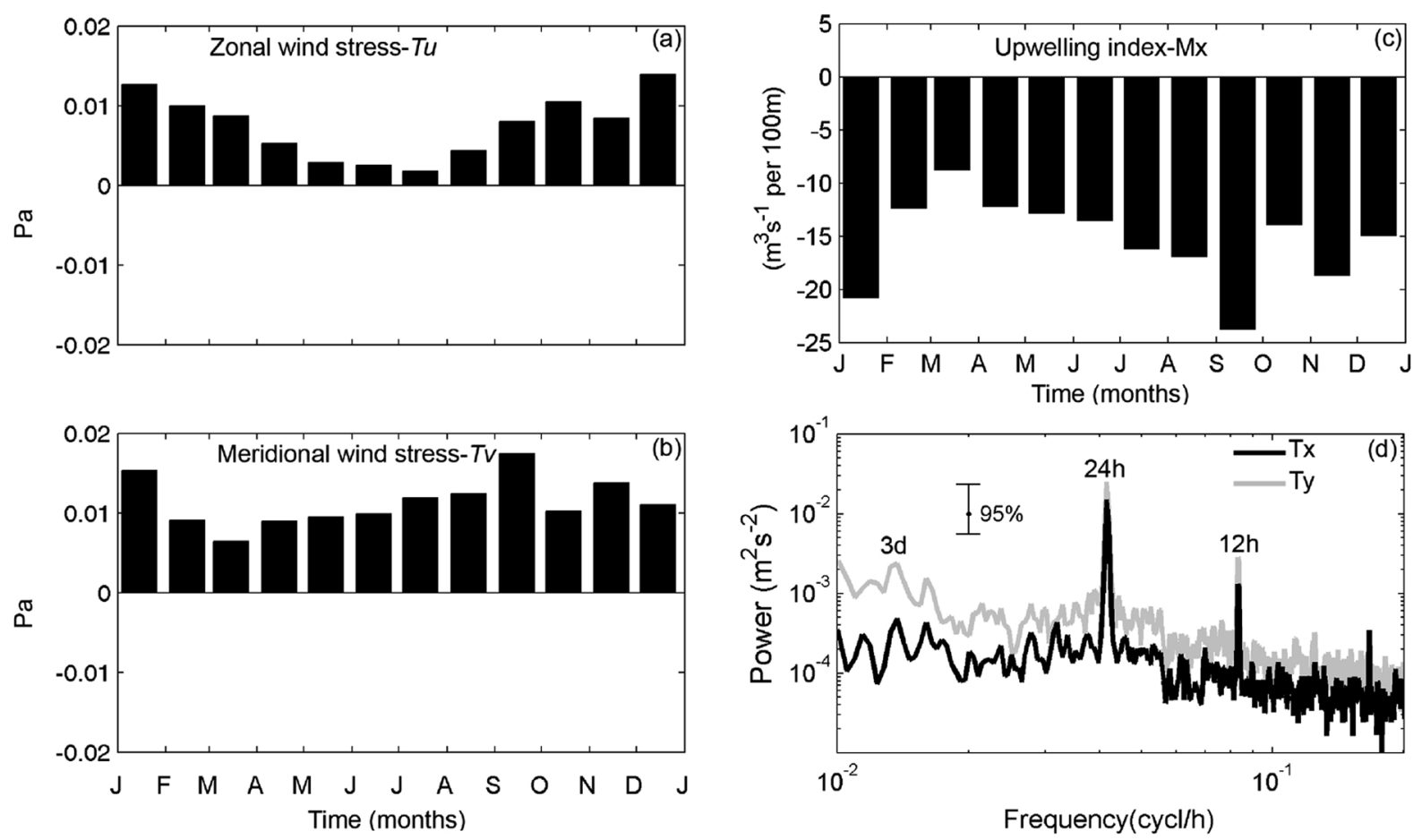

Figure 3. M onthly mean of the (a) zonal and (b) meridional wind stress obtained from the coastal meteorological station in period January 2013 to January 2014. (c) Monthly mean of upwelling index and (d) Fourier spectral analysis to the zonal and meridional wind stress/ Promedio mensual de (a) estrés de viento zonal y (b) meridional obtenido de la estación metereológica costera durante Enero 2013 a Enero 2014. (c) Promedio mensual del índice de surgencia y (d) análisis espectral de Fourier del estrés del viento zonal y meridional

however during the sampling period diurnal cycles of strong upwelling (7 such events) alternated with downwelling conditions (Fig. 4d). During winter 2014 downwelling conditions predominated, although 2 consecutive days (12-13 July) of upwelling conditions were registered during the sampling period (Fig. 4e).

The above patterns are further examined and corroborated following the approach proposed by Bograd et al. (2009), whereby the cumulative upwelling index allows for a sounder distinction of the upwelling favorable periods with summer, winter 2013 and spring being the clearest ones (Fig. 5).

\section{ZOOPLANKTON COMMUNITY COMPOSITION}

From a total of 166 taxa that were encountered, $123(74.1 \%)$ were identified at the species level, $39(23.5 \%)$ at the level of genera and $4(2.4 \%)$ at other lower taxonomic levels, and categorized as follows: 48 holoplankton taxa, 8 meroplankton taxa, 51 copepods (separated from the rest of the holoplankton due to their high abundance), 35 decapods larvae, and 24 taxa of ichthyoplankton (eggs and larvae). Throughout the study period, a total of 55 taxa (33.5\% of the total) of the above mentioned were present in every season (Table 1).

\section{ZOOPLANKTON DISTRIBUTION AND ABUNDANCE}

The abundance of the principal groups occurring within Totoralillo bay as well as outside its boundaries varied greatly throughout the study period. Summer 2013 registered the lowest overall abundance of zooplankton $\left(<490000\right.$ ind. $\left.100 \mathrm{~m}^{-3}\right)$, while the highest was observed during winter $2014(<5950000$ ind. $100 \mathrm{~m}^{-3}$ ) (Fig. 6). Copepods were always the most abundant group over the study period $(65.3 \%)$ mainly represented by Acartia tonsa and Paracalanus cf. indicus, followed by meroplankton (17.6\%), independently from where samples were collected.

These patterns can be graphically appreciated when reviewed as total abundance at each of the sampling points over each of the sampling periods (Fig. 7). Noteworthy is the high abundance of zooplankton within the bay of Totoralillo Norte during winter 2014, although no sampling was conducted outside of the bay during that period. When samples were taken from all points, including those outside the bay, highest abundances were always recorded in the points closest to the coast, regardless of seasonality. From a seasonal perspective, copepods were numerically dominant throughout the study, although exhibited greater abundance during fall and winter periods of each year. 

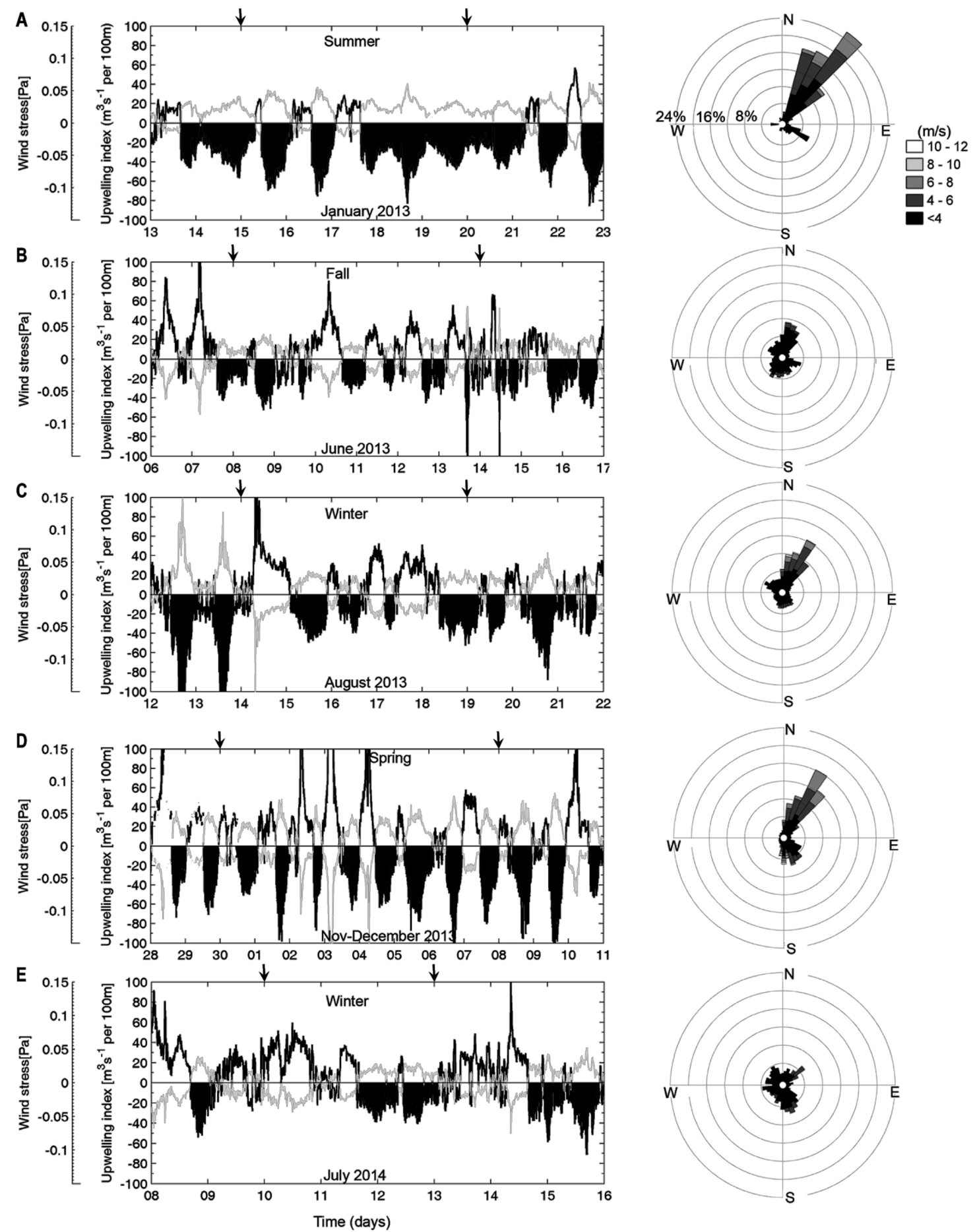

Figure 4. (a-e) Hourly upwelling index (black lines) derived from in-situ wind data (grey lines). Arrows indicate the starting and ending dates, respectively, for the sampling period within each season. Right panels depict the average wind direction during the month of the respective surveys I (a-e) Índice de surgencia por hora (líneas negras) derivado de los datos de viento in-situ (líneas grises). Las flechas indican los datos iniciales y finales, respectivamente, para el periodo de muestreo dentro de cada estación del año. Paneles a la derecha representan la dirección promedio del viento durante el mes de las mediciones respectivas 


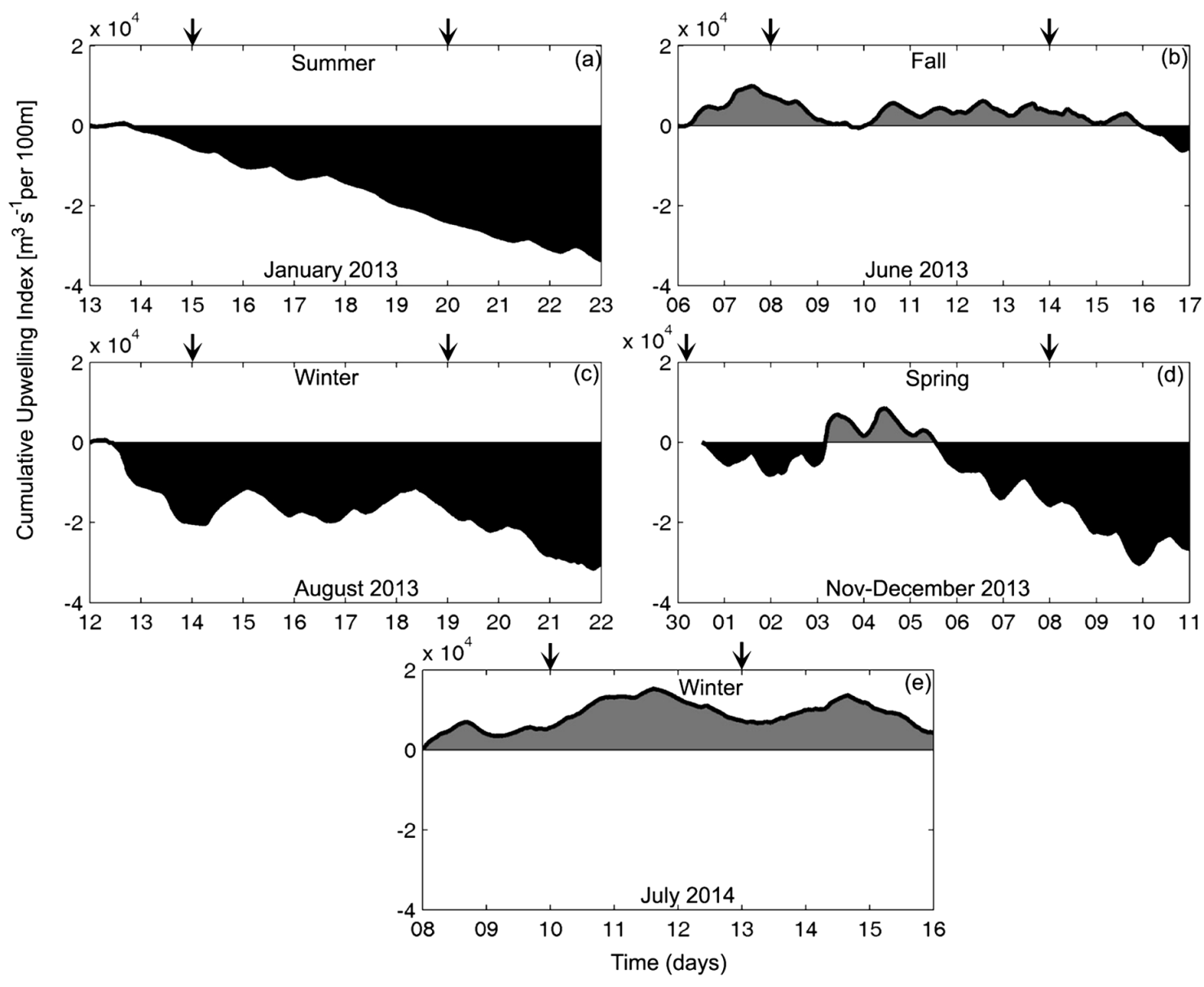

Figure 5. Cumulative upwelling index for the surveyed periods. The sampling period are marked with arrows. Black/grey shaded areas denote favorable upwelling/ downwelling conditions / Índice de surgencia acumulado para los períodos analizados. Los períodos de muestreo se marcan con flechas. Áreas negro/gris indican condiciones de surgencia/ hundimiento

The holoplankton, meroplankton and fish eggs did not show marked differences among seasons, although their abundance was higher during the winter 2014. Decapods exhibited a remarkable higher abundance during the winter 2014 season while fish larvae were fairly well represented during all seasons except spring, and fish larvae exhibited some abundance peaks during winter 2013 (Fig. 7).

\section{ZOOPLANKTON COMMUNITY STRUCTURE AND ABUNDANCE DYNAMICS}

Numerically the zooplankton was more abundant in samples collected during the winter 2014 than during the remaining seasons. A descriptive statistical summary for zooplankton group abundances is shown in Table 2. Throughout this study zooplankton abundance was highly variable in the study area, ranging from 0 in the case of fish larvae to $>1$ million of individuals per $100 \mathrm{~m}^{3}$ in the case of copepods. The latter group accounts for $64 \%$ of the overall zooplankton abundance followed by meroplankton which accounted for $22 \%$ in abundance. Differences in the community structure between seasons were statistically significant (ANOSIM test, Global R=0.249, $P<$ 0.0001 ) as well as among different wind regimes (ANOSIM test, Global R=0.194, $P<0.0001$ ) (Table 3).

In relation to the changes observed in the zooplankton abundances, the Kruskal-Wallis test (multiple comparisons) showed statistical differences between seasons and upwelling regimes (Table 4). Strongest statistical differences $(P<0.00001)$ were observed between contrasting seasons (e.g., summer versus winter) and a higher influence of moderate and weak upwelling events than strong Ekman transport (Table 4). 
Summer 2013

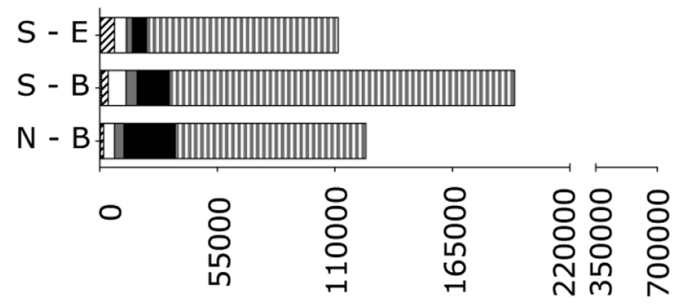

Fall 2013

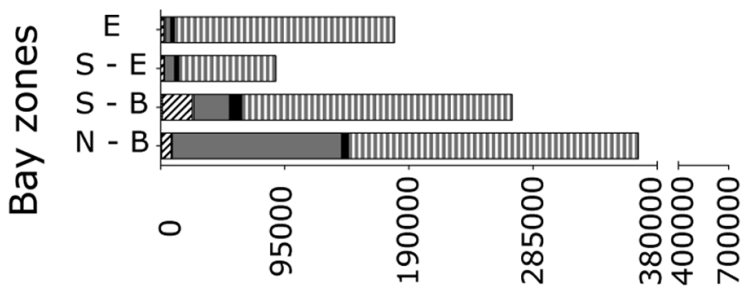

Spring 2013

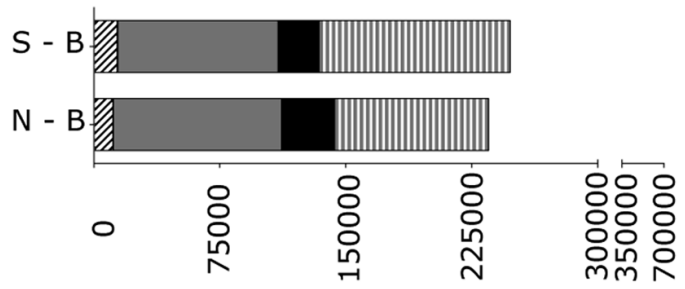

Fish larvae

Z Holoplankton

Fish eggs

Meroplankton

Decapods

II Copepods

Individuals $100 \mathrm{~m}^{-3}$

Figure 6 Average abundance (individual $100 \mathrm{~m}^{-3}$ ) for each zooplankton category from summer 2013 to winter 2014 in Totoralillo Norte Bay. Letters identify position of the different sampling points. E=Exterior, S-E=Southern exterior, S-B=Southern bay, N-B =Northern bay (see Fig. 1 for details) / Abundancia promedio (individuos $100 \mathrm{~m}^{-3}$ ) para cada categoría de zooplancton desde verano 2013 hasta invierno 2014 en la bahía Totoralillo Norte. Letras identifican la posición de los diferentes puntos de muestreo. E= Exterior, S-E= Exterior sur, S-B= Bahía sur, N-B= Bahía norte (ver Fig. 1 para detalles)

The non-parametric stepwise multiple regression (BEST analysis) indicates that holoplankton, meroplankton, decapods, fish eggs and copepods were the groups that best correlated with the Ekman transport (Global R= 0.99; correlation= 0.990; $P$-value $=0.001)$, which confirms the influence of coastal upwelling regime on the zooplankton community.

\section{Discussion}

The present study not only provides a detailed and exhaustive list of zooplankton species present in the bay of Totoralillo Norte, but also describes its variability at different spatial (bayscale) and temporal (seasonal) scales. Similar studies exist along the coast of Chile, where detailed patterns of distribution and abundance together with related forcing factors (i.e., wind-driven currents) are provided, although they are generally restricted to a specific group within the zooplanktonic community (i.e., copepods, Escribano \& Hidalgo 2000; gelatinous zooplankton, Palma \& Apablaza 2004; decapod, meroplankton, Palma et al. 2006). Similar such efforts have also been carried out at other latitudes (i.e., California). However, only patterns of distribution and abundance and related processes for single or reduced groups of species were described (i.e. Roughan et al. 2005, Mace \& Morgan 2006a). Seasonal differences in plankton composition and biomass have been described from a variety of marine environments. In high latitudes like the Barents Sea this is mainly related to water mass circulation and bottom topography (Araskkevich et al. 2002) and in a tropical estuarine system in the Persian Gulf the observed changes were mainly related to salinity, chlorophyll a, temperature and $\mathrm{pH}$ differences (Farhadian \& Pouladi 2014). Other examples of changes in plankton composition and abundance along coastal settings 


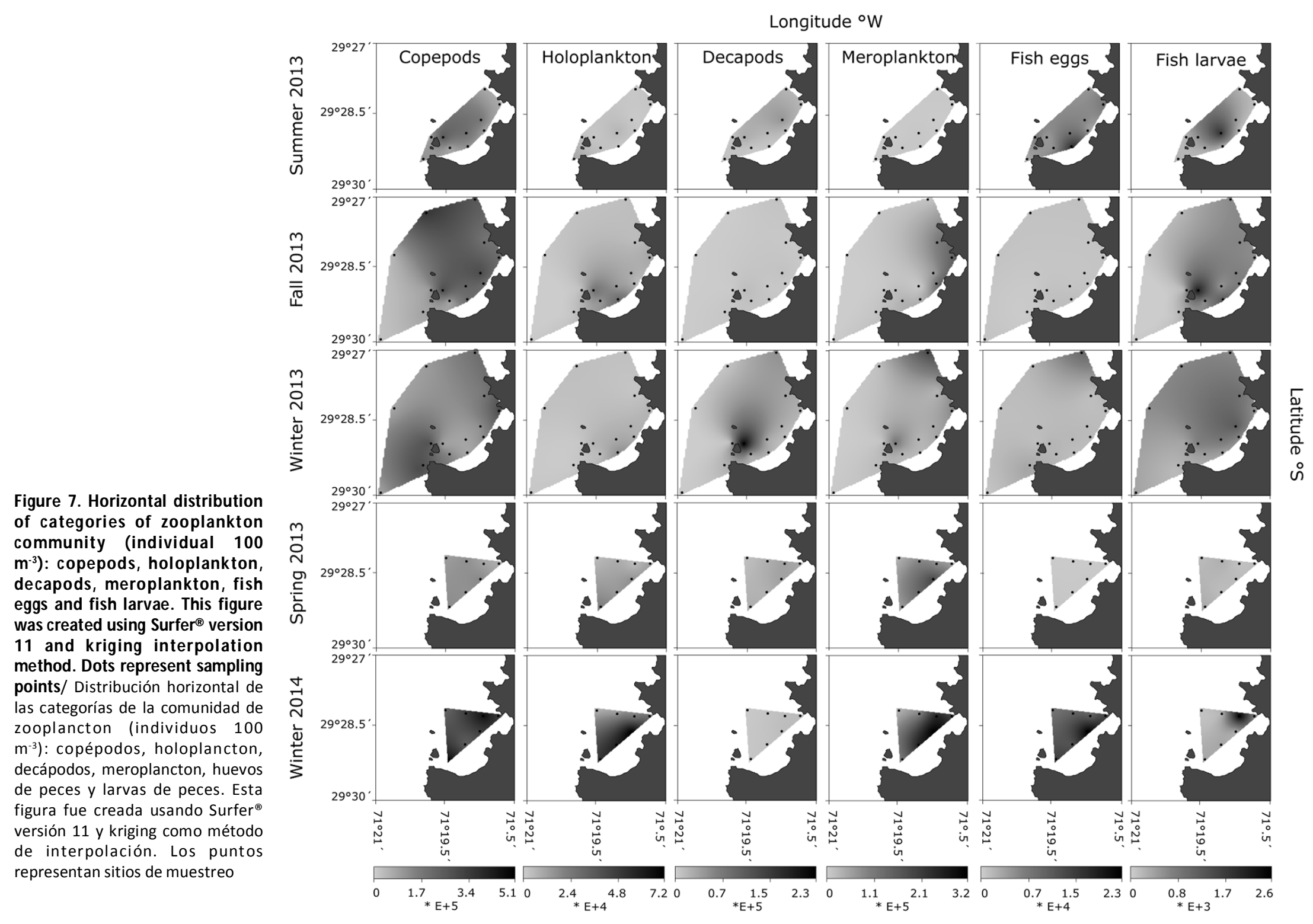


Table 1 List of zooplankton species identified in Totoralillo Bay fromsummer 2013 to winter 2014. ( + ) indicates de presence of aspecies in agiven season. In the case of decapods and fishes the distinction between different lawal stages were made: Z; zoea, M: megriopa, E: egg Li fish lanve. (Cat). inclicates the categories in which the species were grouped: 1: holoplankton, 2i meroplankton, 3: copepods, 4: decapods, 5: fish eggs, 6: fish lanvae/ Lista de especies de zooplancton identificadas en la Bahía de Totoralillo desde el verano 2013 hasta el invierno del 2014. (+) indica la presencia de una especie en una temporada determinada. En el caso de decápodos y peces la distinción entre diferentes estados larvales fueron indicados como: Z: zoea, M: megalopa, E: huevo, L: larva de pez. (Cat.) indica las categorías en que las especies fueron agrupadas: 1: holoplancton, 2: meroplancton, 3: copépodos, 4: decápodos, 5: huevos de peces, 6: larva de pez

\begin{tabular}{|c|c|c|c|c|c|c|c|c|c|c|c|}
\hline \multirow{2}{*}{ Phylum } & \multirow{2}{*}{ Class } & \multirow{2}{*}{ Order } & \multirow{2}{*}{ Family } & \multirow{2}{*}{ Species } & \multirow{2}{*}{ Cat. } & \multirow{2}{*}{$\begin{array}{c}\text { Summer } \\
2013 \\
\end{array}$} & \multirow{2}{*}{$\begin{array}{c}\text { Fall } \\
2013\end{array}$} & \multicolumn{3}{|c|}{ Winter } & \multirow{2}{*}{$\begin{array}{l}\text { Spring } \\
2013 \\
\end{array}$} \\
\hline & & & & & & & & & 013 & 2014 & \\
\hline Rhizaria & Foraminifera & Globigerinida & Globigerinidae & Globigerina sp. & 1 & + & & & & & \\
\hline \multirow[t]{6}{*}{ Cnidaria } & Hydrozoa & Anthoathecata & Bougainvilliidae & Bougainvillia $\mathrm{sp}$. & 1 & + & & & & & \\
\hline & & & Corymorphidae & Euphysa aurata & 1 & + & & & + & & \\
\hline & & & Corynidae & Sarsia eximia & 1 & + & + & & + & + & + \\
\hline & & & & Stauridiosarsia sp. & 1 & + & & & & & \\
\hline & & & Pandeidae & Leuckartiara octona & 1 & + & + & & & & \\
\hline & & & Tubulariidae & Ectopleura dumortierii & 1 & + & + & & + & + & + \\
\hline Cnidaria & Hydrozoa & Hydroida & Oceanidae & Turritopsis nutricula & 1 & & & & + & & + \\
\hline Cnidaria & Hydrozoa & Leptomedusae & Campanulariidae & Obelia sp. & 1 & + & + & & + & + & + \\
\hline \multirow[t]{3}{*}{ Cnidaria } & Hydrozoa & Leptothecata & Phialellidae & Phialella quadrata & 1 & + & + & & + & + & + \\
\hline & & & Campanulariidae & Phialidium sp. & 1 & + & + & & + & + & + \\
\hline & & & Eirenidae & Phialopsis diegensis & 1 & & & & & & + \\
\hline Cnidaria & Hydrozoa & Narcomedusae & Cuninidae & Cunina perigrima & 1 & & & & & & + \\
\hline \multirow[t]{4}{*}{ Cnidaria } & Hydrozoa & Siphonophorae & Abylidae & Abylopsis tetragona & 1 & + & + & & + & & + \\
\hline & & & Diphyidae & Muggiaea atlantica & 1 & + & + & & + & & + \\
\hline & & & Calycophorae & Sphaeronectes gracilis & 1 & & & & & & + \\
\hline & & & Prayidae & Rosacea sp. & 1 & & & & & & \\
\hline \multirow[t]{3}{*}{ Cnidaria } & Hydrozoa & Trachymedusae & Geryoniidae & Liriope tetraphylla & 1 & & & & & + & + \\
\hline & & & Halicreatidae & Botrynema brucei & 1 & + & & & + & & \\
\hline & & & Rhopalonematidae & Sminthea eurygaster & 1 & + & + & & & & + \\
\hline Cnidaria & Scyphozoa & Coronatae & Periphylla & Periphylla periphylla & 1 & & & & & & + \\
\hline Ctenophora & Nuda & Beroida & Beroidae & Beroe cucumis & 1 & + & & & & + & + \\
\hline Ctenophora & Tentaculata & Cydippida & Pleurobrachiidae & Pleurobrachia sp. & 1 & + & + & & + & + & + \\
\hline Platyhelminthes & Rhabditophora & Polycladida & Notoplanidae & Notoplana sp. & 2 & & + & & + & + & + \\
\hline Annelida & Polychaeta & Aciculata & Tomopteridae & Tomopteris sp. & 1 & + & + & & + & + & + \\
\hline \multirow{2}{*}{ Annelida } & Polychaeta & Phyllodocida & Alciopidae & Vanadis $\mathrm{sp}$. & 1 & + & & & & & \\
\hline & & & & & & $\mathrm{Z} \quad \mathrm{M}$ & $\mathrm{Z} \mathrm{M}$ & & $\mathrm{M}$ & $\mathrm{Z} \mathrm{M}$ & Z M \\
\hline \multirow[t]{10}{*}{ Arthropoda } & Malacostraca & Decapoda (Anomura) & Albuneidae & Lepidopa sp. & 4 & + & ++ & + & & + & \\
\hline & & & Blepharipodidae & Blepharipoda sp. & 4 & + & + & + & & + & + \\
\hline & & & Hippidae & Emerita analoga & 4 & $+\quad+$ & ++ & + & + & ++ & ++ \\
\hline & & & Munididae & Cervimunida johni & 4 & & & + & & + & + \\
\hline & & & & Pleuroncodes monodon & 4 & + & + & + & & + & + \\
\hline & & & Paguridae & Pagurus sp. & 4 & + & ++ & + & + & + & ++ \\
\hline & & & Porcellanidae & Allopetrolisthes angulosus & 4 & + & ++ & + & + & + & ++ \\
\hline & & & & Petrolisthes granulosus & 4 & $+\quad+$ & ++ & + & + & + & ++ \\
\hline & & & & Petrolisthes violaceus & 4 & + & + & + & + & + & ++ \\
\hline & & & & Porcellana & 4 & $+\quad+$ & ++ & & + & ++ & ++ \\
\hline Arthropoda & Malacostraca & Decapoda (Axiidea) & Callianassidae & Callianassa sp. & 4 & + & + & + & & + & + \\
\hline \multirow{5}{*}{ Arthropoda } & Malacostraca & Decapoda (Brachyura) & Aethridae & Hepatus chiliensis & 4 & & & & & & + \\
\hline & & & Atelecyclidae & Pseudocorystes sicarius & 4 & & & & + & & + \\
\hline & & & Belliidae & Acanthocyclus albatrossis & 4 & & & & & & + \\
\hline & & & & Acanthocyclus gayi & 4 & + & + & + & + & ++ & + \\
\hline & & & & Corystoides chilensis & 4 & & + & + & + & ++ & + \\
\hline
\end{tabular}




\begin{tabular}{|c|c|c|c|c|c|c|c|c|c|c|}
\hline & & & Cancridae & Cancer coronatus & 4 & & & & + & + \\
\hline & & & & Cancer porteri & 4 & & & & + & + \\
\hline & & & & Cancer setosus & 4 & & ++ & ++ & + & + \\
\hline & & & Epialtidae & Pisoides edwardsii & 4 & + & ++ & ++ & ++ & + \\
\hline & & & & Taliepus dentatus & 4 & + & ++ & ++ & ++ & + \\
\hline & & & Grapsidae & Leptograpsus variegatus & 4 & + & + & ++ & ++ & + \\
\hline & & & Hymenosomatidae & Halicarcinus planatus & 4 & + & + & ++ & + & + \\
\hline & & & Inachoididae & Pyromaia tuberculata & 4 & & & & & \\
\hline & & & Majidae & Eurypodius latreillei & 4 & & ++ & ++ & + & + \\
\hline & & & & Libidoclaea granaria & 4 & & + & & & + \\
\hline & & & Pilumnoididae & Pilumnoides perlatus & 4 & + & + & & + & + \\
\hline & & & Pinnotheridae & Pinnixa sp. & 4 & + & + & + & ++ & + \\
\hline & & & & Pinnotheres sp. & 4 & & & & ++ & + \\
\hline & & & Platyxanthidae & Homalaspis plana & 4 & + & ++ & ++ & ++ & + \\
\hline & & & & Platyxanthus sp. & 4 & & + & + & + & + \\
\hline & & & Portunidae & Ovalipes sp. & 4 & & & & & \\
\hline & & & Trichopeltariidae & Peltarion spinulosum & 4 & & & & & \\
\hline & & & Varunidae & Cyclograpsus cinereus & 4 & + & ++ & ++ & ++ & + \\
\hline & & & Xanthidae & Paraxanthus barbiger & 4 & & & & & \\
\hline Arthropoda & Malacostraca & Halocyprida & Halocyprididae & Conchoecia sp. & 1 & + & + & + & + & + \\
\hline Arthropoda & Malacostraca & Euphausiacea & Euphausiidae & Euphausia mucronata & 1 & + & + & + & & + \\
\hline & & & & Euphausia sp. & 1 & & & + & & + \\
\hline & & & & Stylocheiron sp. & 1 & & & + & & \\
\hline Arthropoda & Malacostraca & Amphipoda & Hyperiidae & Hyperia sp. & 1 & + & & & & \\
\hline & & & Lestrigonidae & Hyperietta sp. & 1 & + & + & + & + & + \\
\hline & & & & Lestrigonus schizogeneios & 1 & + & + & + & + & \\
\hline & & & Phronimidae & Phronima sedentaria & 1 & & & + & & \\
\hline & & & Phrosinidae & Primno macropa & 1 & & + & & & \\
\hline & & & Vibiliidae & Vibilia armata & 1 & & + & + & + & + \\
\hline Arthropoda & Malacostraca & Isopoda & Cirolanidae & Cirolana sp. & 1 & + & + & + & + & + \\
\hline & & Cumacea & Bodotriidae & Cyclaspis sp. & 1 & & + & + & & \\
\hline Arthropoda & Malacostraca & Mysida & Mysidae & Mysidae NI & 2 & + & + & & + & + \\
\hline Arthropoda & Malacostraca & Stomatopoda & Gonodactylidae & Gonodactylidae NI & 2 & + & + & + & + & + \\
\hline Arthropoda & Maxillopoda & Calanoida & Acartiidae & Acartia tonsa & 3 & + & + & + & + & + \\
\hline & & & Aetideidae & Aetideus armatus & 3 & + & + & + & + & + \\
\hline & & & & Chiridius poppei & 3 & & + & + & & + \\
\hline & & & & Euchirella sp. & 3 & & + & + & & \\
\hline & & & & Gaetanus sp. & 3 & & & & & + \\
\hline & & & Augaptilidae & Haloptilus acutifrons & 3 & & & + & & \\
\hline & & & Calanidae & Calanoides patagonensis & 3 & + & & & & \\
\hline & & & & Calanus chilensis & 3 & + & + & + & + & + \\
\hline & & & & Mesocalanus tenuicornis & 3 & + & + & + & + & + \\
\hline & & & & Nannocalanus minor & 3 & + & + & + & + & + \\
\hline & & & Centropagidae & Centropages brachiatus & 3 & + & + & + & + & + \\
\hline & & & & Centropages bradyi & 3 & & & & + & \\
\hline
\end{tabular}


Clausocalanus ingens

Clausocalanus jobei

Microcalanus pygmaeus

Eucalanidae Eucalanus hyalinus

Subeucalanus subtenuis

Euchaetidae

Euchaeta marina

Heterorhabdidae Heterorhabdus abyssalis

Heterorhabdus papilliger

Lucicutiidae

Lucicutia sp.

Metridinidae

Metridia lucens

$\begin{array}{ll} & \text { Pleuromamma gracilis } \\ \text { Paracalanidae } & \text { Acrocalanus monachus }\end{array}$

Calocalanus pavo

Calocalanus tenuis
Paracalanus cf. indicus

Rhincalanidae

Rhincalanus nasutus

Scolecitrichidae

Lophothrix sp.

Scaphocalanus sp.

Scolecithricella abyssalis

Scolecithrix bradyi

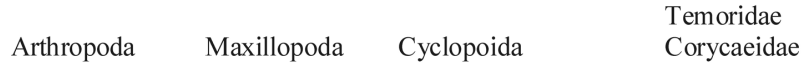

Temora sp.

Corycaeus erythraeus

Corycaeus lautus

Corycaeus typicus

Oithonidae Oithonanana

Oithona setigera

Oithona similis

Oncaeidae Oncaea venusta

Triconia conifera

Sapphirinidae Sapphirina sp.

$\begin{array}{llll}\text { Arthropoda Maxillopoda Harpacticoida } & \text { incertae sedis } & \text { Pachos punctatum } \\ & \text { Clytemnestrida } & \text { Clytemnestra rostrata }\end{array}$

Clytemnestra scutellata

Ectinosomatidae

Arthropoda Maxillopoda Siphonostomatoida

Microsetella norvegica

Arthropoda Maxillopoda Sessilia

Arthropoda

Branchiopoda Cladocer

Podonidac

Caligus sp.

Mollusca

Gastropoda

Mesogastropoda

Podonidae

Atlantidae

Pterotracheidae

Evadne sp.

Atlanta sp.

Firoloida desmaresti

Thecosomata
Neogastropoda

Muricidae

Peraclis apicifulva

Octopoda Octopodidae

Octopus sp.

Membraniporidae

Sagittidae

Membranipora sp.

Bryozoa Gymnolaemata Cheilostomatic

Aphragmophora

Sagitta bipunctata

Sagitta enflata

Sagittidae Sagitta lyra

Sagittidae $\quad$ Sagitta maxima

Sagittidae

Sagitta maxima 


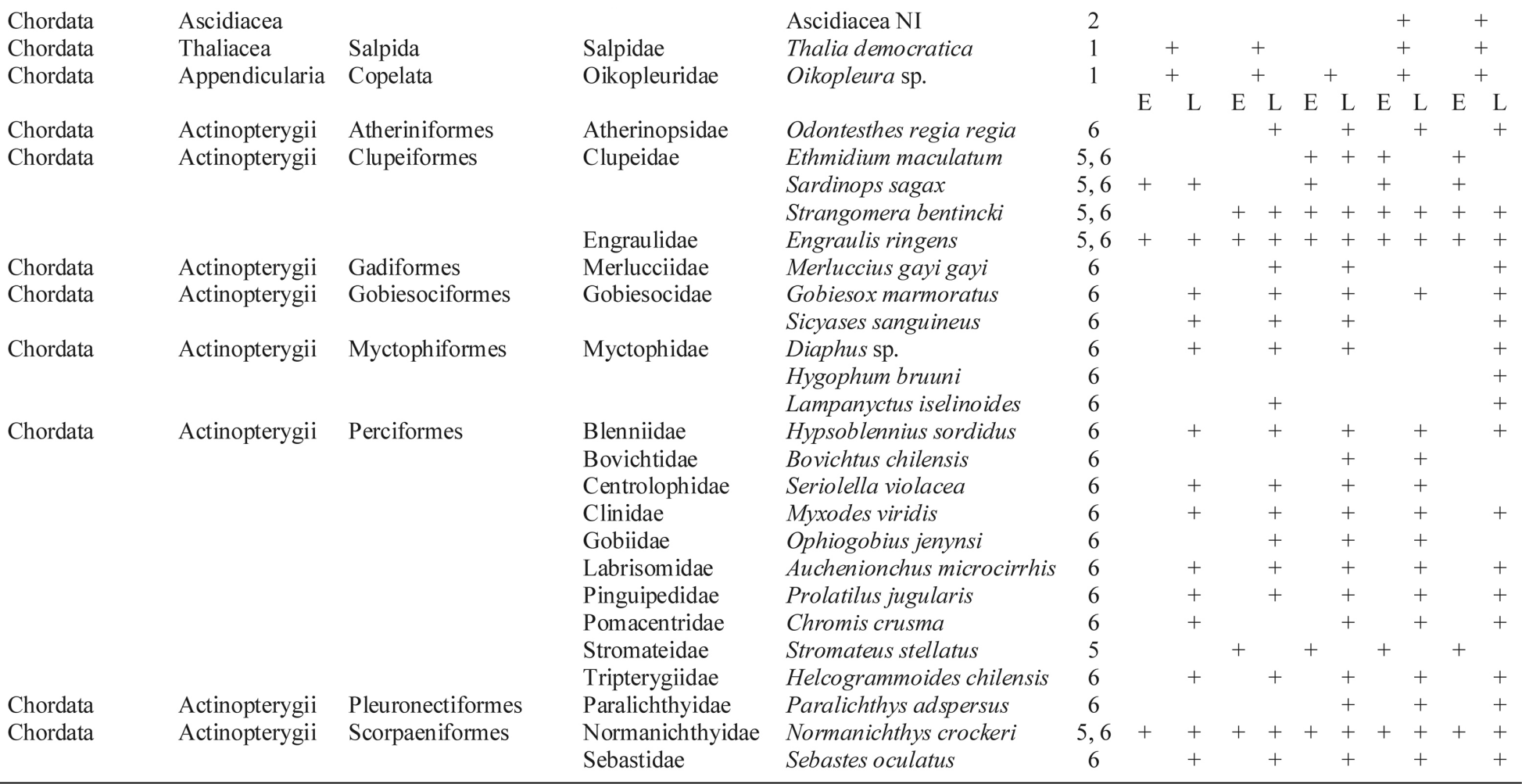


Table 2. Statistical summary for zooplankton abundance by category (Individuals $100 \mathrm{~m}^{-3}$ ) in relation to seasons and wind regimes (cumulated Ekman transport, CET) in Totoralillo Norte Bay, northern Chile. CET values were categorized as downwelling (DWN, $\approx 14,000 \mathrm{~m}^{2} \mathrm{~s}^{-1}$ ), weak upwelling (LUP, $\approx 20,000 \mathrm{~m}^{2} \mathrm{~s}^{-1}$ ), moderate upwelling (MUP, $\approx 40,000 \mathrm{~m}^{2} \mathrm{~s}^{-1}$ ) and

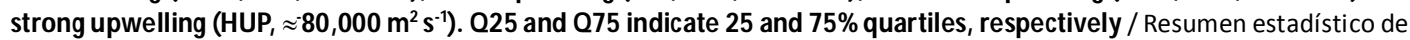
la abundancia de zooplancton por categoría (Individuos $100 \mathrm{~m}^{-3}$ ) en relación a estaciones del año y regímenes de viento (Transporte de Ekman acumulado, CET) en bahía Totoralillo Norte, Norte de Chile. Valores CET fueron categorizados como convergencia (DWN, $\approx 14,000 \mathrm{~m}^{2} \mathrm{~s}^{-1}$ ), surgencia débil (LUP, $\approx 20,000 \mathrm{~m}^{2} \mathrm{~s}^{-1}$ ), surgencia moderada (MUP, $\approx 40,000 \mathrm{~m}^{2} \mathrm{~s}^{-1}$ ) y surgencia fuerte (HUP, $\approx 80,000 \mathrm{~m}^{2} \mathrm{~s}^{-1}$ ). Q25 y Q75 indican los cuartiles 25 y $75 \%$ respectivamente

\begin{tabular}{|c|c|c|c|c|c|c|c|c|}
\hline Category & Season & Median & Q25 & Q75 & $\begin{array}{c}\text { Ekman } \\
\text { effect }\end{array}$ & Median & Q25 & Q75 \\
\hline \multirow[t]{5}{*}{ Holoplankton } & Summer 2013 & 1385 & 590 & 3564 & MUP & 1385 & 590 & 3564 \\
\hline & Fall 2013 & 8652 & 5247 & 20942 & DWN & 8652 & 5247 & 20942 \\
\hline & Winter 2013 & 2327 & 1386 & 8620 & HUP & 2327 & 1386 & 8620 \\
\hline & Spring 2013 & 12551 & 2056 & 31612 & LUP & 14962 & 4181 & 49556 \\
\hline & Winter 2014 & 45532 & 13371 & 74844 & & & & \\
\hline \multirow[t]{5}{*}{ Meroplankton } & Summer 2013 & 3608 & 1516 & 8508 & MUP & 3608 & 1516 & 8508 \\
\hline & Fall 2013 & 6881 & 3257 & 13969 & DWN & 6881 & 3257 & 13969 \\
\hline & Winter 2013 & 33177 & 20030 & 54060 & HUP & 33177 & 20030 & 54060 \\
\hline & Spring 2013 & 19922 & 9224 & 107887 & LUP & 70122 & 14876 & 185943 \\
\hline & Winter 2014 & 149810 & 70122 & 356808 & & & & \\
\hline \multirow[t]{5}{*}{ Decapods } & Summer 2013 & 11686 & 2899 & 26959 & MUP & 11686 & 2899 & 26959 \\
\hline & Fall 2013 & 3036 & 1621 & 5535 & DWN & 3036 & 1621 & 5535 \\
\hline & Winter 2013 & 10595 & 7051 & 46196 & HUP & 10595 & 7051 & 46196 \\
\hline & Spring 2013 & 18684 & 8830 & 39093 & LUP & 14455 & 6072 & 28745 \\
\hline & Winter 2014 & 7651 & 3550 & 18331 & & & & \\
\hline \multirow[t]{5}{*}{ Fish eggs } & Summer 2013 & 4169 & 3461 & 11096 & MUP & 4169 & 3461 & 11096 \\
\hline & Fall 2013 & 702 & 468 & 1482 & DWN & 702 & 468 & 1482 \\
\hline & Winter 2013 & 890 & 409 & 2643 & HUP & 890 & 409 & 2643 \\
\hline & Spring 2013 & 53 & 21 & 938 & LUP & 988 & 38 & 12781 \\
\hline & Winter 2014 & 14849 & 11543 & 23144 & & & & \\
\hline \multirow[t]{5}{*}{ Fish larvae } & Summer 2013 & 275 & 124 & 652 & MUP & 275 & 124 & 652 \\
\hline & Fall 2013 & 516 & 266 & 825 & DWN & 516 & 266 & 825 \\
\hline & Winter 2013 & 483 & 197 & 1071 & HUP & 483 & 197 & 1071 \\
\hline & Spring 2013 & 158 & 98 & 296 & LUP & 232 & 102 & 361 \\
\hline & Winter 2014 & 333 & 191 & 417 & & & & \\
\hline \multirow[t]{5}{*}{ Copepods } & Summer 2013 & 67732 & 14113 & 199841 & MUP & 67732 & 14113 & 199841 \\
\hline & Fall 2013 & 119538 & 82111 & 197496 & DWN & 119538 & 82111 & 197496 \\
\hline & Winter 2013 & 99854 & 57770 & 161902 & HUP & 99854 & 57770 & 161902 \\
\hline & Spring 2013 & 53821 & 14562 & 118739 & LUP & 140663 & 34117 & 292465 \\
\hline & Winter 2014 & 290837 & 239939 & 327971 & & & & \\
\hline
\end{tabular}


Table 3. Analysis of similarity (ANOSIM) showing Global R and pairwise test for differences among seasons and wind regimes (cumulated Ekman transport, CET) in Totoralillo Bay, northern Chile. CET values were categorized as downwelling (DWN, $\approx 14,000 \mathrm{~m}^{2} \mathrm{~s}^{-1}$ ), weak upwelling (LUP, $\approx 20,000 \mathrm{~m}^{2} \mathrm{~s}^{-1}$ ), moderate upwelling (MUP, $\approx \mathbf{4 0 , 0 0 0}$

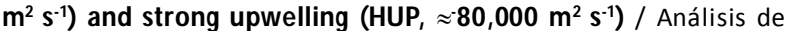
similitud (ANOSIM) que muestra el $R$ global y comparaciones pareadas para diferentes estaciones del año y regímenes de viento (Transporte de Ekman acumulado, CET) en bahía Totoralillo Norte, norte de Chile. Valores de CET fueron categorizados como convergencia (DWN, $\approx 14,000 \mathrm{~m}^{2} \mathrm{~s}^{-1}$ ), surgencia débil (LUP, $\approx 20,000$ $\mathrm{m}^{2} \mathrm{~s}^{-1}$ ), surgencia moderada (MUP, $\approx 40,000 \mathrm{~m}^{2} \mathrm{~s}^{-1}$ ) y surgencia fuerte (HUP, $\approx 80,000 \mathrm{~m}^{2} \mathrm{~s}^{-1}$ )

\begin{tabular}{lcc}
\hline & R Statistic & p-value \\
\hline Pairwise Tests for Season & & \\
Sample statistic (Global R): 0.369 & & \\
Summer 2013 vs Fall 2013 & 0,250 & 0,0002 \\
Summer 2013 vs Winter 2013 & 0,262 & 0,0002 \\
Summer 2013 vs Spring 2013 & 0,390 & 0,0001 \\
Summer 2013 vs Winter 2014 & 0,626 & 0,0001 \\
Fall 2013 vs Winter 2013 & 0,241 & 0,0005 \\
Fall 2013 vs Spring 2013 & 0,291 & 0,0002 \\
Fall 2013 vs Winter 2014 & 0,657 & 0,0001 \\
Winter 2013 vs Spring 2013 & 0,156 & 0,0060 \\
Winter 2013 vs Winter 2014 & 0,698 & 0,0001 \\
Spring 2013 $v s$ Winter 2014 & 0,484 & 0,0001 \\
Pairwise Tests for Ekman effect & & \\
Sample statistic (Global R): 0.213 & & \\
MUP $v s$ DWN & 0,250 & 0,0002 \\
MUP $v s$ HUP & 0,262 & 0,0003 \\
MUP $v s$ LUP & 0,340 & 0,0001 \\
DWN $v s$ HUP & 0,241 & 0,0007 \\
DWN $v s$ LUP & 0,168 & 0,0030 \\
HUP $v s$ LUP & 0,077 & 0,0560 \\
\hline
\end{tabular}

include a strong human-related pollution/eutrophication that alters natural seasonal changes (Kwang-Hyeon et al. 2009). Here, we describe the seasonal dynamics of the entire zooplankton community for an important spatial span of the coastal area, including sites close to shore ( 200 m) to points well outside the bay of Totoralillo Norte (several $\mathrm{km}$ offshore) stressing on the relevance of hydrographic processes that not necessarily operate with similar strength on a seasonal basis. Such basic understanding of how a wide variety of zooplankton behaves both spatially and temporally is fundamental given the degree of anthropic intervention over coastal environments (Viles $\&$ Spencer 2014).
From October 2012 through November 2014, we uncovered a seasonal pattern regarding the thermal structure of the water column and prevailing winds of Totoralillo Norte Bay consistent with patterns of seasonal occurrence of upwelling conditions (i.e. peak upwelling typically observed during the Spring-Summer seasons) that have been described for this area of the Chilean coastline (Montecino \& Quiroz 2000, Montecino et al. 2005, Letelier et al. 2009, Tapia et al. 2009). Moreover, the high temporal sampling frequency used in this study revealed that upwelling events can be frequent in this bay even in seasons (i.e., winter 2013) when they are least expected.

These wind stress patterns were integrated with zooplankton abundance data in order to assess how upwelling may determine the distribution and abundance patterns of zooplankton at these specific spatial (bay) and temporal (seasonal) scales (Tapia et al. 2004, Daneri et al. 2012). Generally, upwelling events result in higher plankton abundance towards the interior parts of bays (Mace \& Morgan 2006a, b; Palma et al. 2006, Vander Woude et al. 2006, Morgan \& Fisher 2010). The mechanisms by which this occurs are not evident, since superficial plankton should be transported off-shore by advection (Wing et al. 1995, Miller \& Emlet 1997, Morgan \& Fisher 2010, Morgan et al. 2012), but may be associated with the high retention rates at protected systems (Roughan et al. 2005, Mace \& Morgan 2006a) or alternatively with the ability of certain groups within the zooplankton to move throughout the water column (i.e., daily vertical migration) and thus avoid being advected offshore (Poulin et al. 2002b, Sponaugle et al. 2002). For instance, in upwelling regions, upwelling shadows form in the lee of large headlands and are characterized by reduced local wind forcing, localized reversal of alongshore flow, and warm surface waters (Graham \& Largier 1997). When the wind is not sufficiently diminished by a small headland (which is the case of Totoralillo) alongshore transport of surface water into the bay with recirculation at depth can occur, more so during upwelling events, and can promote retention of plankton, particularly the type capable of daily vertical migration (Roughan et al. 2005). Our results are coherent with such previous studies showing increased abundance in the inner part of Totoralillo bay. However, the novelty found here is that this pattern emerges not only on an annual basis, but during all seasons studied.

In this study, we found higher abundance of zooplankton in winter 2014 that were concomitant with downwelling prevailing conditions, particularly during the sampling period (i.e., 10-13 July 2014). Such an association between local wind patterns and zooplankton abundance may indicate that stronger winds do not necessarily imply higher zooplankton abundances, but rather calm or variable periods promote higher concentration 
Table 4. Kruskal-Wallis test of multiple comparisons for statistical differences in the zooplankton abundances between seasons and upwelling regimes in Totoralillo Norte Bay, northern Chile. CET values were categorized as downwelling (DWN, $\approx 14,000 \mathrm{~m}^{2} \mathrm{~s}^{-1}$ ), weak upwelling (LUP, $\approx 20,000$

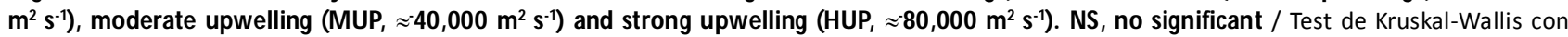
comparaciones múltiples para diferencias estadísticas en las abundancias del zooplancton entre estaciones y regímenes de surgencia en bahía Totoralillo Norte, Norte de Chile. Valores de CET fueron categorizados como convergencia (DWN, $\approx 14,000 \mathrm{~m}^{2} \mathrm{~s}^{-1}$ ), surgencia débil (LUP, $\approx 20,000 \mathrm{~m}^{2}$ $\mathrm{s}^{-1}$ ), surgencia moderada (MUP, $\approx 40,000 \mathrm{~m}^{2} \mathrm{~s}^{-1}$ ) y surgencia fuerte (HUP, $\approx 80,000 \mathrm{~m}^{2} \mathrm{~s}^{-1}$ ). NS, valor no significativo

\begin{tabular}{|c|c|c|c|c|c|c|}
\hline \multirow{2}{*}{$\frac{\text { Category }}{\text { Holoplankton }}$} & \multicolumn{2}{|c|}{ Seasons } & \multirow{2}{*}{$\begin{array}{l}P \text {-value } \\
<0.05\end{array}$} & \multicolumn{2}{|c|}{ Upwelling regimes } & \multirow{2}{*}{$\begin{array}{l}P \text {-value } \\
<0.05\end{array}$} \\
\hline & Summer $2013 v s$ & Fall 2013 & & MUP vs & DWN & \\
\hline & Summer $2013 v s$ & Spring 2013 & $<0.05$ & MUP vs & LUP & $<0.0001$ \\
\hline & Summer $2013 v s$ & Winter 2014 & $<0.00001$ & HUP vs & LUP & $<0.01$ \\
\hline & Winter $2013 v s$ & Winter 2014 & $<0.0001$ & & & \\
\hline \multirow[t]{4}{*}{ Meroplankton } & Summer $2013 v s$ & Winter 2013 & $<0.01$ & MUP vs & HUP & $<0.001$ \\
\hline & Summer $2013 v s$ & Spring 2013 & $<0.001$ & MUP vs & LUP & $<0.00001$ \\
\hline & Summer $2013 v s$ & Winter 2014 & $<0.00001$ & $\mathrm{DWN} v s$ & LUP & $<0.01$ \\
\hline & Fall $2013 v s$ & Winter 2014 & $<0.001$ & & & \\
\hline \multirow[t]{2}{*}{ Decapods } & Fall 2013 vs & Winter 2013 & $<0.01$ & $\mathrm{DWN} v s$ & HUP & $<0.01$ \\
\hline & Fall $2013 v s$ & Spring 2013 & $<0.001$ & $\mathrm{DWN} v s$ & LUP & $<0.01$ \\
\hline \multirow[t]{5}{*}{ Fish eggs } & Summer $2013 v s$ & Fall 2013 & $<0.01$ & MUP $v s$ & DWN & $<0.01$ \\
\hline & Summer $2013 v s$ & Spring 2013 & $<0.00001$ & MUP vs & LUP & $<0.05$ \\
\hline & Fall $2013 v s$ & Winter 2014 & $<0.0001$ & & & \\
\hline & Winter $2013 v s$ & Winter 2014 & $<0.001$ & & & \\
\hline & Spring $2013 v s$ & Winter 2014 & $<0.00001$ & & & \\
\hline \multirow[t]{2}{*}{ Fish larvae } & Fall $2013 v s$ & Spring 2013 & $<0.05$ & $\mathrm{DWN} v s$ & LUP & $<0.05$ \\
\hline & Winter $2013 v s$ & Spring 2013 & $<0.01$ & HUP vs & LUP & $<0.05$ \\
\hline \multirow[t]{3}{*}{ Copepods } & Summer $2013 v s$ & Winter 2014 & $<0.01$ & NS & & \\
\hline & Winter $2013 v s$ & Winter 2014 & $<0.05$ & & & \\
\hline & Spring $2013 v s$ & Winter 2014 & $<0.001$ & & & \\
\hline
\end{tabular}

of pelagic organisms by influencing (increasing) the retention times within bays like Totoralillo. Similarly, Cury \& Roy (1989) demonstrated that fish larvae recruitment was highest at intermediate, rather than strong upwelling intensity in the Peruvian, California, Moroccon, and Senegalese upwelling systems.

We identified 166 taxa, highlighting the importance that these environments have for holoplanktonic species, and the role of such species in coastal trophic webs (Escribano 1998, Vargas et al. 2006, El-Sabaawi et al. 2010). This is also true for meroplankton, and emphasis should be placed in realizing how these coastal environments serve as breeding/nursery grounds for pelagic species (i.e., anchovies and sardines HernándezMiranda et al. 2003) or nurseries for benthic species (i.e., decapod crustaceans Palma et al. 2006, mollusks Poulin et al. $2002 \mathrm{a}, \mathrm{b}$ ). If the prevailing physical conditions (i.e., occurrence of upwelling or downwelling favorable events) alongside other mechanisms -that determine the patterns of zooplankton distribution and abundance- are recurring; then it becomes of utmost importance to recognize that embayment systems, such as Totoralillo Norte, represent discrete, yet complex environments along the Chilean coast and their conservation should be a priority that future sustainable endeavors should embrace. 


\section{ACKNOWLEDGMENTS}

We are grateful to the colleagues and students that contributed to this study. Special thanks to the editorial committee of $\mathrm{RBM} \& \mathrm{O}$ and the comments provided by two anonymous reviewers for critical reviews of earlier drafts. During this research IP-S was funded by the FONDECYT grant 11140161 and COPAS SUR-AUSTRAL grant PFB-31. This study was supported by AndesIron Spa.

\section{LITERATURE CITED}

Acuña E, J Moraga \& E Uribe. 1989. La zona de Coquimbo: un sistema nerítico de surgencia de alta productividad. Revista de la Comisión Permanente del Pacífico Sur, Número Especial: 145-157.

Arashkevich E, P Wassmann, A Pasternak \& C Wexels. 2002. Seasonal and spatial changes in biomass, structure, and development progress of the zooplankton community in the Barents Sea. Journal of Marine Systems 38: 125-145.

Bograd S, JI Schroeder, N Sarkar, X Qiu, WJ Sydeman \& FB Schwing. 2009. Phenology of coastal upwelling in the California Current. Geophysical Research Letters 36, L01602 <doi:10.1029/2008GL035933>

Clarke KR. 1993. Non-parametric multivariate analyses of changes in community structure. Austral Journal of Ecology 18:117-143. 〈doi:10.1111/j.1442-9993.1993.tb00438.x>

Clarke KR \& RM Warwick. 2001. Change in marine communities: An approach to statistical analysis and interpretation, 172 pp. PRIMER-E, Plymouth.

Clarke KR \& RN Gorley. 2006. PRIMER v6: User Manual/ Tutorial, 192 pp. PRIMER-E, Plymouth.

Cury P \& C Roy. 1989. Optimal environmental window and pelagic fish recruitment success in upwelling areas. Canadian Journal of Fisheries and Aquatic Sciences 46(4): 670-680.

Daneri G, L Lizárraga, P Montero, HE González \& FJ Tapia. 2012. Wind forcing and short-term variability of phytoplankton and heterotrophic bacterioplankton in the coastal zone of the Concepción upwelling system (Central Chile). Progress in Oceanography 92: 92-96.

EI-Sabaawi RW, AR Sastri, JF Dower \& A Mazumder. 2010. Deciphering the seasonal cycle of copepod trophic dynamics in the Strait of Georgia, Canada, using stable isotopes and fatty acids. Estuaries and Coasts 33: 738-752.

Escribano R. 1998. Population dynamics of Calanus chilensis in the Eastern Boundary Humboldt Current. Fisheries Oceanography 7: 245-251.

Escribano R \& P Hidalgo. 2000. Spatial distribution of copepods in the north of the Humboldt Current region off Chile during coastal upwelling. Journal of the Marine Biological Association of the United Kingdom 80: 283-290.

Escribano R, VH Marín \& P Hidalgo. 2001. The influence of coastal upwelling on the distribution of Calanus chilensis in the Mejillones Peninsula (northern Chile): implications for its population dynamics. Hydrobiologia 453: 143-151.
Escribano R, G Daneri, L Farías, V Gallardo, H González, D Gutiérrez, C Lange, C Morales, O Pizarro, $O$ Ulloa \& M Braun. 2004. Biological and chemical consequences of the 1997-1998 El Niño in the Chilean coastal upwelling system: a synthesis. Deep-Sea Research Part II 51: 2389-2411.

Farhadian O \& M Pouladi. 2014. Seasonal changes in the abundance and biomass of zooplankton from shallow mudflat river-estuarine system in Persian Gulf. Brazilian Journal of Aquatic Science and Technology 18: 19-29.

Field JG, KR Clarke \& RM Warwick. 1982. A practical strategy for analyzing multispecies distribution patterns. Marine Ecology Progress Series 8: 37-52.

Giraldo A, R Escribano \& V Marín. 2002. Spatial distribution of Calanus chilensis off Mejillones Peninsula (northern Chile): ecological consequences upon coastal upwelling. Marine Ecology Progress Series 230: 225-234.

Graham WM \& JL Largier. 1997. Upwelling shadows as nearshore retention sites: the example of northern Monterey Bay. Continental Shelf Research 17: 509-532.

Henríquez LA, G Daneri, C Muñoz, P Montero, R Veas \& AT Palma. 2007. Primary production and phytoplanktonic biomass in shallow marine environments of central Chile: Effect of coastal geomorphology. Estuarine, Coastal and Shelf Science 73: 137-147.

Kwang-Hyeon C, D Hideyuki, N Yuichiro, O Yumiko \& N Shin-ichi. 2009. Spatial and temporal distribution of zooplankton communities of coastal marine waters receiving different human activities (Fish and Pearl Oyster Farmings). The Open Marine Biology Journal 3: 83-88.

Letelier J, O Pizarro \& S Nuñez. 2009. Seasonal variability of coastal upwelling and the upwelling front off central Chile. Journal of Geophysical Research: Oceans 114. C12009, <doi:10.1029/2008JC005171>

Mace A \& S Morgan. 2006a. Biological and physical coupling in the lee of a small headland: contrasting transport mechanisms for crab larvae in an upwelling region. Marine Ecology Progress Series 324: 185-196.

Mace A \& S Morgan. 2006b. Larval accumulation in the lee of a small headland: implications for the design of marine reserves. Marine Ecology Progress Series 318: 19-29.

Marín V, L Delgado \& R Escribano. 2003. Upwelling shadows at Mejillones Bay (northern Chilean coast): a remote sensing in situ analysis. Investigaciones Marinas 31(2): 47-55.

Marín VH, L Delgado \& G Luna-Jorquera. 2007. SChlorophyll squirts at $30^{\circ} \mathrm{S}$ off the Chilean coast (eastern South Pacific): feature-tracking analysis. Journal of Geophysical Research: Oceans 108(C12): 3378.

Marta-Almeida M, J Dubert, A Peliz \& H Queiroga. 2006. Influence of vertical migration pattern on retention of crab larvae in a seasonal upwelling system. Marine Ecology Progress Series 307: 1-19.

Miller B \& RB Emlet. 1997. Influence of nearshore hydrodynamics on larval abundance and settlement of sea urchins Strongylocentrorus franciscanus and $S$. purpuratus in the Oregon upwelling zone. Marine Ecology Progress Series 148: 83-94. 
Montecino V \& D Quiroz. 2000. Specific primary production and phytoplankton cell size structure in an upwelling area off the coast of Chile (30 $\left.{ }^{\circ} \mathrm{S}\right)$. Aquatic Sciences 62: 364-380.

Montecino V, PT Strub, FP Chavez, AC Thomas, J Tarazona \& T Baumgartner. 2005. Bio-physical interactions off western South America. In: Robinson AR \& KH Brink (eds). The Sea, pp. 329-390. Harvard University Press, Cambridge.

Moraga J, E Valdebenito \& J Rutllant. 2001. Condiciones oceanográficas durante la fase de relajación de un evento de surgencia invernal frente a Punta Lengua de Vaca, Coquimbo. Investigaciones Marinas 29: 59-71.

Morgan S \& J Fisher. 2010. Larval behavior regulates nearshore retention and offshore migration in an upwelling shadow and along the open coast. Marine Ecology Progress Series 404: 109-126.

Morgan SG, JL Fisher, ST McAfee, JL Largier \& CM Halle. 2012. Limited recruitment during relaxation events: larval advection and behavior in an upwelling system. Limnology and Oceanography. 57: 457-470.

Palma S \& P Aplablaza. 2004. Abundancia estacional y distribución vertical del zooplancton gelatinoso carnívoro en un área de surgencia en el norte del Sistema de la Corriente de Humboldt. Investigaciones Marinas, Valparaíso 32: 49-70.

Palma AT, L Pardo, R Veas, C Cartes, M Silva, K Manríquez, A Díaz, C Muñoz \& FP Ojeda. 2006. Coastal brachyuran decapods: settlement and recruitment under contrasting coastal geometry conditions. Marine Ecology Progress Series 316: 139-153.

Palma AT, LA Henríquez \& FP Ojeda. 2009. Phytoplanktonic primary production in a highly dynamic environment in central Chile modulated by coastal geomorphology: a short-term effect. Revista de Biología Marina y Oceanografía 44: 325-334.

Palma AT, I Cáceres-Montenegro, R Bennet, S Magnolfi, L Henríquez, J Guerra, K Manriquez \& E Palma. 2011. Near-shore distribution of phyllosomas of two only lobster species (Decapoda: Achelata) present in Robinson Crusoe Island and endemic to the Juan Fernández archipiélago. Revista Chilena de Historia Natural 84: 379-390.

Poulin E, AT Palma, G Leiva, D Narvaez, R Pacheco, SA Navarrete \& JC Castilla. 2002a. Avoiding offshore transport of competent larvae during upwelling events: the case of the gastropod Concholepas concholepas in Central Chile. Limnology and Oceanography 47:1248-1255.

Poulin E, AT Palma, G Leiva, E Hernández, P Martínez, SA Navarrete \& JC Castilla. 2002b. Temporal and spatial variation in the distribution of epineustonic competent larvae of Concholepas concholepas along the central coast of Chile. Marine Ecology Progress Series 229: 95-104.
Roughan M, AJ Mace, JL Largier, SG Morgan, JL Fisher \& ML Carter. 2005. Subsurface recirculation and larval retention in the lee of a small headland: A variation on the upwelling shadow theme. Journal of Geophysical Research: Oceans 110:C10.

Rutllant J, I Masotti, J Calderón \& S Vega. 2004. A comparison of a spring coastal upwelling off Central Chile at the extremes of the 1996-1997 ENSO cycle. Continental Shelf Research 24: 773-787.

Sponaugle S, RK Cowen, A Shanks, SG Morgan, JM Leis, J Pineda, GW Boehlert, MJ Kingsford, KC Lindeman, C Grimes \& JL Munro. 2002. Predicting self-recruitment in marine populations: biophysical correlates and mechanisms. Bulletin of Marine Science 70: 341-375.

Tapia FJ, J Pineda, FJ Ocampo-Torres, HL Fuchs, PE Parnell, P Montero \& S Ramos. 2004. High-frequency observations of wind-forced onshore transport at a coastal site in Baja California. Continental Shelf Research 24: 15731585.

Tapia FJ, SA Navarrete, M Castillo, BA Menge, JC Castilla, J Largier, EA Wieters, BL Broitman \& JA Barth. 2009. Thermal indices of upwelling effects on innershelf habitats. Progress in Oceanography 83: 278-287.

Thiel M, E Macaya, E Acuña, W Arntz, H Bastias, K Brokordt, P Camus, JC Castilla, L Castro, M Cortés, C Dumont, R Escribano, M Fernández, J Gajardo, C Gaymer, I Gómez, A González, H González, P Haye, JE Illanes, JL Iriarte, D Lancellotti, G Luna-Jorquera, C Luxoro, P Manríquez, V Marín, P Muñoz, SA Navarrete, E Pérez, E Poulin, J Sellanes, H Sepúlveda, W Stotz, F Tala, A Thomas, C Vargas, J Vásquez \& A Vega. 2007. The Humboldt Current system of northerncentral Chile: Oceanographic processes, ecological interactions and socio-economic feedback. Oceanography and Marine Biology: An Annual Review 45: 195-345.

Vander Woude AJ, JL Largier \& RM Kudela. 2006. Nearshore retention of upwelled waters north and south of Point Reyes (northern California)-Patterns of surface temperature and chlorophyll observed in CoOP WEST. Deep Sea Research Part II 53(25): 2985-2998.

Vargas CA, R Escribano \& S Poulet. 2006. Phytoplankton food quality determines time windows for successful zooplankton reproductive pulses. Ecology 87: 2992-2999.

Viles H \& T Spencer. 2014. Coastal problems: geomorphology, ecology and society at the coast, $360 \mathrm{pp}$. Routledge, New York.

Wing SR, LW Botsford \& JF Quinn. 1995. Settlement and transport of benthic invertebrates in an intermittent upwelling region. Limnology and Oceanography 40: 316-329. 